Mijo Korade

DOI: https://dx.doi.org/10.21857/moxpjhw4km Izvorni znanstveni članak

Rukopis prihvaćen za tisak: 11.12.2019.

\title{
ANTUN KANIŽLIĆ I VINCENZO BASILE: KANIŽLIĆEVA DJELA U DALMACIJI U 19. STOLJEĆU
}

\section{Sažetak}

U članku se nastoji utvrditi koliko su i na koji način Kanižlićeva djela bila prisutna u Dalmaciji i uopće u južnoj Hrvatskoj u 19. stoljeću. Već su u misijsku knjižicu ili pjesmaricu riječkih pučkih misionara pod naslovom Knižica duhovna (Trnava 1768) u najvećem dijelu sadržaja, to jest među misijske pjesme, uvrštene neke Kanižlićeve pjesme (kao npr. Pismu novu svi pivajmo). Veliki molitvenik Bogoljubnost molitvena Antuna Kanižlića doživio je treće izdanje 1806. kod zadarskog tiskara Battare. Sicilijanski isusovac Vincenzo Basile, koji je s Antonijem Ayalom od 1852. držao pučke misije po Dalmaciji i kasnije po čitavoj Hrvatskoj, u treće izdanje svoje knjižice duhovnih razmatranja Razmišljajte ova dobro oca Bartola Baudrand (Zadar 1854) unio je kao dodatak Kanižlićeve molitve. U četvrtom izdanju istog djela Razmišljaj ovo dobro (Rim 1865) donio je dodatak, s posebnom paginacijom, pod naslovom Kratka promišljanja i molitve oca Antuna Kanižlića. Isti je dodatak tiskan i kao zasebna knjižica $\left(12^{\circ}, 138\right.$ str.). U njemu su razmišljanja za svaki dan u mjesecu, svagdašnje molitve, liturgijske molitve pod misom, za ispovijed i pričest te pojedinim svecima, uglavnom iz molitvenika Bogoljubnost molitvena.

Basile je priredio i novo izdanje Kanižlićeva djela Primogući $i$ sardce nadvladajući uzroci s kripostnimih podpomočmah za ljubiti Gospodina Isukarsta Spasitelja našega... (Zagreb 1760) s novim naslovom i preuređeno prema novom pravopisu: Važni uzroci s kojih Gospodina Isukrsta Spasitelja našega nada sve ljubiti moramo $i$ njeka spasonosna sredstva kojim se ova ljubav probuditi može (Požega 1864). Skratio je Kanižlićev predgovor i dodao na kraju svagdašnje molitve. Talijanski isusovac Cesare Luigi Ferrari objavljuje molitvenik za jednu dubrovačku udrugu pod naslovom Blago duhovno ili molitve nadarene svetiem proštenjima... (Verona 1865). U njemu donosi dosta Kanižlićevih molitava i razmatranja, kao i drugih starijih pisaca (B. Kašića, I. M. Matijaševića i dr.). Priručnik dalmatinskih misionara Molitvenik za katolička poslanstva po jugoslovinskih deržavah, koji je 1863. - 1902. doživio pet izdanja, na različite je načine ovisan i povezan s Kanižlićevim molitvenikom Bogoljubnost molitvena.

Ključne riječi: Antun Kanižlić; Vincenzo Basile; Dalmacija; 19. stoljeće; molitvenici; pučke misije. 


\section{Uvod}

Antun Kanižlić veći je dio svog radnog vijeka proveo u rodnoj Požegi, gdje je i napisao sva svoja djela. Pisao ih je narječjem ili govorom svoga kraja, štokavskom ikavicom, i namijenio ih je svome gradu i okolici, ali i čitavom slavonskom kraju, jednako ona objavljena za njegova života i ona s jednim ili više izdanja, kao i ona objavljena nakon njegove smrti. Ipak su neka njegova djela prelazila granice Slavonije, kao katekizam Bogoslovica, od kojega su dva izdanja štampana za Hrvate u istočnoj Ugarskoj i Bačkoj (u Kaločkoj nadbiskupiji), zatim prijevod istog katekizma na kajkavskom i izdanje molitvenika Bogoljubnost molitvena koncem 19. stoljeća u Zagrebu. Osobito je zanimljiva prisutnost Kanižlićevih djela u Dalmaciji u drugoj polovici 19. stoljeća, uglavnom povezana s djelatnošću tamošnjeg pučkog misionara Vincenza Basilea. Ta višestruka povezanost Kanižlića s južnom Hrvatskom i dalmatinskim misionarom Basileom tema je ovoga rada.

\section{Prvi odjeci Antuna Kanižlića u južnoj Hrvatskoj}

Već u 18. stoljeću Kanižlić je prisutan i u jednoj misijskoj knjižici koju su riječki isusovci objavili 1768. godine. Patri iz Riječkog kolegija (1632. - 1773.) držali su pučke misije po Hrvatskom primorju, Istri i središnjoj Hrvatskoj (Senjsko-modruškoj biskupiji), uglavnom kontinuirano, kroz veći dio 17. i 18. stoljeća. Postojala je u kolegiju i stalna služba propovjednika, od kojih su mnogi i kao pučki misionari obilazili spomenute krajeve. Ti misionari objavili su i mali priručnik za misije pod naslovom: Knižica duhovna u četiri dili razdiljena: $U$ koje pervomu se dade način štiti; $u$ drugomu kratak Nauk karstjanski; $u$ tretjomu Pisme bogoljubne; u četvartomu Proštjenja misionu udiljena. Složena iz mnogih knjižicah od ocih misionarih Družbe Isusove Ričkoga koleja (sic!), na službu bližnjih slavnih biskupijih, osobito pako Senjske i Modruške. U Ternavi, U Pritiskalnici Družbe Isusove, 1768. $\left(16^{\circ}, 96 \text { str. }\right)^{1}$

Od tih četiriju dijelova knjižice koji se spominju u naslovu, najkraći je prvi s uputom za čitanje, sličan onima kakve su Kanižlić i drugi dijelili u Požegi, samo je malo kraći. Katekizam je dulji (str. 5-21), prema strukturi Bellarminova katekizma² i sličan je onima kakve su objavljivali Bernard Zuzorić3 ${ }^{3}$ Juraj Mulih i drugi u svojim moli-

1 Mijo Korade, Misijski katekizmi u južnoj Hrvatskoj u 18. stoljeću, Kateheza, 20 (1998) 4, 346-348; Knjižicu donose i Vatroslav Frkin i Miljenko Holzleitner, Bibliografija knjiga hrvatskih autora u knjižnicama Hrvatske franjevačke provincije sv. Ćirila i Metoda 1495.-1850., HAZU, Zagreb 2008, 258; Josip Jakšić, Četiri stoljeća hrvatskih katekizama, 1578-1980, Zagreb 1995, 96.

2 Jakšić pogrešno navodi o knjižici: „Molitvenik s kratkim izvatkom Kanizijeva katekizma“, J. Jakšić, Četiri stoljeća, 96.

3 Dubrovački isusovac Bernard Zuzorić (1683. - 1762.) djelovao je kao pučki misionar 1724. - 1742. na istome području Senjsko-modruške biskupije, Primorja i Istre. Objavio je dva mala misijska priručnika s katekizmom i pjesmama Hvale duhovne i Nauk kerstjanski (1729, 1730, 1752). Miroslav Vanino, Isusovci i hrvatski narod, III, Zagreb 2005, 109-118, 143-149. M. Korade, Misijski katekizmi, 344-346. 
tvenicima i misijskim knjižicama. Najveći dio tog misijskog priručnika zapremaju pjesme i litanije koje su se pjevale u misijama (str. 22-81). Tu je skupljen pregršt pjesama i litanija koje su se to vrijeme pjevale za vrijeme misija. Više je pjesama koje su se pjevale nakon pojedinih tematskih propovijedi, kao naprimjer o ispovijedi, skrušenju i pokajanju, o grijehu, o posljednjim čovjekovim stvarima (smrt, sud, pakao, raj), o Majci Božjoj, svecima i sl. Mnoge su takove misijske pjesme već dulje vrijeme bile uobičajene $u$ misijama riječkih patara, a mnoge su preuzete iz drugih misijskih knjižica i pjesmarica, kao iz Hvale duhovne Bernarda Zuzorića (Marijo zvizdo mora, Ja se kajem Bože mili...), ili iz Mulihove pjesmarice Bogoljubne pisme (1736.), u kojoj ima Kanižlićevih pjesama (Zdravo sunce božanstveno), ili Svi jezici hvale dajte slavnom tilu Spasitelja, parafraza crkvenog himna Pange lingua iz Kanižlićeva molitvenika Bogoljubnost molitvena (1766.). Od Kanižlića je i njegova poznata pjesma iz Male i svakom potribne bogoslovice (1760.) - Pisma u kojoj mladići Isusa, a divojke Mariu na izminju i zajedno fale. Prva kitica glasi:

1. M (mladići) Pismu novu svi pivajmo,

D (divojke) Pivajuć se izminjajmo,

M (mladići) Mi od Sinka zapivajuć.

D (divojke) Mi od Majke odpivajuć

Z (zajedno) Sinka s Majkom slavimo. ${ }^{4}$

U zadnjem su dijelu knjižice (82-96) tumačenje misijskih oprosta i uobičajene molitve, a sasvim na kraju djela vjere, ufanja, ljubavi i skrušenja, koja se ne razlikuju puno od onih kod Zuzorića, u Mulihovim pjesmaricama ili u Kanižlićevu katekizmu Bogoslovica. Tako su priređivači Knižice Duhovne, a vjerojtno su to bili tadašnji riječki pučki misionari Leopold Locatelli i (ili) Juraj Mordax, ${ }^{5}$ približili Kanižlićeve stihove središnjoj Hrvatskoj, Istri i Primorju.

Početkom 19. stoljeća jedno Kanižlićevo djelo objavljeno je ponovno u Zadru kod tiskara Battare. Radi se o vrlo zanimljivom i vrijednom djelu kojemu je potrebno podrobnije opisati izdanja i sadržaj. Puni naslov prvoga izdanja glasi: Bogoljubnost molitvena, na poštenje Prisvete Troice, Jedinoga Boga, Blažene Divice Marie i svetih, s različitim naucih $i$ istomačenjem svetih običajah cerkvenih. Složena i prikazana svetomu Aloisii Družbe Isusove ispovidniku od Antuna Kanižlića, Družbe iste misnika. U Ternavi, 1766. (m8 ${ }^{\circ}, \mathrm{XV}+/ 17 /+580$ str.).

4 Opis pjesama iz Knižice Duhovne vidi u M. Vanino, Isusovci, III, 165-173.

5 Prvi je Vanino donio hipotezu o autorstvu te dvojice misionara, što je vrlo vjerojatno. M. Vanino, Isusovci, III, 173; M. Korade, Misijski katekizmi, 348. O Locatellijevu misijskom radu vidi M. Korade, Hrvatski isusovci misionari, Zagreb 1991, 95-98. 
Identično po naslovu i broju stranica izlazi drugo izdanje u Budimu 1794. godine. Treće izdanje izlazi u Zadru kod tiskara Battare 1806. godine. Ima identičan naslov kao i dva prijašnja izdanja, jedino na naslovnici nema godine izdanja nego je samo na kraju opis tiskara: „U utistaonici Antona Luigia Battare“. Jednak je format: mali $8^{\circ}, \mathrm{XV}+/ 17 /+644$ str., a identičan je i sadržaj. (Vidi se da je broj stranica dosta veći od prvoga izdanja, a razlog je vjerojatno u različitom slogu). Prema tablici pomičnih blagdana, koja počinje s godinom 1806., u kalendaru (na nepaginiranim stranicama) očito je da je molitvenik tiskan $1806 .{ }^{6}$

Za četvrto izdanje u naslovu, istome kao i u prvome, dodano je: „Pritiskanje novo od pervoga izversnije poboljšano“, a objavljeno je u „Budimu, Pritiskano slovami Mudro učene skupčine Peštanske, 1813.“ (m8 , XV+/17/+564 str.), (znači malo manje stranica samoga teksta molitvenika s obzirom na prva dva izdanja). ${ }^{7}$

Peto izdanje priredio je zagrebački kanonik Franjo Iveković pod naslovom: Pobožnost molitvena na slavu Presvetoj Trojici, jedinomu Bogu i na čast Blaženoj Djevici Mariji i svetima. Različitim naucima is tumačenjem svetih običaja crkvenih, spisao Antun Kanižlić svećenik Družbe Isusove. Izdanje priredio Dr. F. Iveković kanonik. Na svijet izdalo Društvo Svetojeronimsko. Zagreb 1893. Izašlo je dakle u nakladi Hrvatskoga književnog društva sv. Jeronima (Pučka knjižnica, sv. 89; u osmini ima 653 str., tiskano u 15.000 primjeraka). ${ }^{8}$ Iveković je Kanižlićev tekst ponegdje nešto skratio ili promijenio, a modernizirao je jezik. Na kraju je dodao Kršćanski nauk iliti Katehisam (str. 577635), a u bilješci je napomenuo da je to „Katolički katehizam za III. razred pučkih škola. U Zagrebu 1892“ (dakle jedan od tadašnjih školskih izdanja tzv. „Austrijskog katekizma“). Sasvim na kraju običajne su molitve Oče naš i sl. (str. 636-640). ${ }^{9}$

Taj neobični molitvenik, u usporedbi sa sličnim izdanjima sve do 20. stoljeća, vjerojatno spada među najvrednija u starijoj hrvatskoj molitvenoj literaturi, moglo bi ga se nazvati i knjigom razmatranja, pa i objašnjenja kršćanskih istina, osobito pak vjerskih obreda i sakramenata. Glavne karakteristike molitvenika istaknuo je Kanižlić već u samom naslovu. Znači radi se o molitvenoj pobožnosti u slavu Trojstva, jedinog Boga, Blažene Djevice Marije i svetaca (tj. temeljnih subjekata kršćanske vje-

\footnotetext{
Ima ga Knjižnica HAZU u Zagrebu.

7 Prvo, drugo i četvrto izdanje donosi Frkin-Holzleitner, Bibliografija, 241-242, s osnakom u kojim franjevačkim samostanskim knjižnicama postoje primjerci pojedinih izdanja.

8 Josip Buturac, 100 godina Hrvatskog književnog društva sv. Jeronima ili sv. Ćirila i Metoda 1868-1968, Zagreb 1969, 78.

9 Na samom početku, nakon naslovnice, na trećoj je stranici poseban naslov: „Kanižlićeva molitvenica“. Nakon Kanižlićeva skraćenog predgovora, „Iz predgovora piščeva“, slijedi pregled pomičnih svetkovina u razdoblju 1893. - 1920., zatim kalendar i „Tumačenje stvari osobitih, da se bolje razumije koledar" (str. 5-26). U prvom su poglavlju najprije jutarnje molitve, a zatim pouka o promišljanju i razmatranje za svaki dan u mjesecu. Iveković je Pobožnost molitvenu priredio prema četvrtom izdanju, u Budimu 1813. Ispred naslovne je stranice lijepa tada moderna slika u boji s motivom krunjenja Bl. Djevice Marije.
} 
re), zatim o tumačenjima tih kršćanskih otajstava i objašnjenjima crkvenih obreda i sakramenata (s različitim naucih $i$ istomačenjem svetih običajah cerkvenih).

Znakovito je da Kanižlić na kraju naslova naglašava da je djelo složeno i prikazano sv. Alojziju Gonzagi. Također prije predgovora ima nadahnutu posvetu sv. Alojziju: „Anđeoski mladiću sveti Aloisio“ (str. III-VIII) u kojoj veliča njegove kreposti i preporučuje sebe i svu mladež njegovu zagovoru. Budući da je sv. Alojzije tada bio glavni zaštitnik mladeži, kojega su osobito isusovci promicali, a i Kanižlićevi suvremenici i prijatelji Juraj Mulih i Josip Milunović objavili su knjige u čast tome svecu namijenjene mladeži, to bi jedino moglo značiti da i Kanižlić svoj molitvenik namjenjuje prvenstveno mladim ljudima. To se, uostalom, i uklapalo u glavni cilj djelovanja Kanižlića i požeških isusovaca: odgoj mladeži preko škola, misija i opismenjavanja te izdavanje knjiga (katekizama, molitvenika i drugih duhovnih djela).

U „Pridgovoru dobrovoljnom štiocu“ Kanižlić najprije objašnjava nakanu i svrhu molitvenika. Prema njemu, nisu svi bogomoljci pravi bogoljubnici jer „molitva jest dio bogoljubnosti i plod, koji se od nje rađa, ili priprava na nju istu: Bogoljubnost pako, kako uči Naučitelj Anđeoski /tj. sv. Toma Akvinski/, jest volja pripravna i gotova nastojati i dati se na ona, koja su na službu Božju. Bogoljubni dakle po nauku istoga Naučitelja zovu se i jesu oni, koji sebe Bogu cilovito podlažu, kako najvećemu svom Gospodinu, u njega virujući i ufajući, njega ljubeći i poštujući ne samo ričjom, nego i osobito dilom, kerstjanski živući i njegove svete zapovidi ispunjajući.“

Nakon što je opisao sadržaj molitvenika, to jest koje molitve, pobožnosti i tumačenja donosi, nastavlja: „O šuplje i opake glave, šuplje ako još ne razumiju na koji način mi Svete poštujemo, opake akoli razumiući sa svim tim još nas osvađaju“ te donosi pravu malu apologiju katoličkog štovanja svetaca. Na kraju naglašava: „Istomačio sam različite svete običaje cerkvene, koje kerstjanom lipo i korisno za veću Bogoljubnost jest razumiti i znati. Nisu knjige samo zato složene da iz njih molimo, nego i zato da naš Zakon razumimo, da kerstjanski živiti naučimo. ${ }^{\text {.10 }}$

Dakle, Kanižlić u molitveniku ne donosi samo molitve i pobožnosti nego je njima obilato "primišao“ pouke koje će čitatelja poticati na kršćanski život. A što se molitve tiče, on želi da njegovi „štioci“ i razmatraju vječne istine, te ih poučava kako se obavlja mislena ili nutarnja molitva (meditacija) koju on zove "promišljanje“ (str. 14-23), a zatim donosi 31 kratko razmatranje o četiri posljednje stvari (smrt, sud, pakao, raj) za svaki dan u mjesecu (str. 23-48). Nakon jutarnjih i večernjih molitava slijedi opširno tumačenje, $u$ dijaloškom obliku, pojedinih dijelova svete mise i drugih obreda, misničkog ruha i drugih predmeta, povezanih s misom i obredima. $\mathrm{Na}$ isti način tumači osobito sakramente ispovijedi i pričesti, potom obrede i običaje Velikog tjedna i pojedinih crkvenih blagdana i obrede drugih sakramenata. Govoreći o

10 Antun Kanižlić, Bogoljubnost molitvena, Zadar 1806, IX-XV. 
Velikom petku piše: „Što čine danas bogoljubni kršćani? Premda neima danas mise dolaze pomnjivo u crkvu, da budu kod običaja /tj. ceremonija/ i službe crkvene; da slušaju rič i pivanje Muke i smrti Isukrstove; da sveti sakrament u grob sadruže. Mnogi o suhu kruhu poste, pohode Kalvariu, gdi se nahodi, i u različitih crkvah grob Isukrstov; razmišljaju bogoljubno otajstva Muke i smrti Isuskrsatove. ${ }^{\prime 11}$

Mnogo stranica posvećuje štovanju muke i smrti Isusove, gdje uključuje i pravila $\mathrm{s}$ molitvama, poukom i oprostima Bratovštine muke i smrti Isusove. ${ }^{12}$ Velik prostor posvećuje pobožnosti („,bogoljubnost na poštenje“) Mariji i pojedinim svecima s oficijima, litanijama, raznim pobožnostima s razmatranjima, molitvama i pjesmama. Zadnji dio molitvenika obuhvaća „bogoljubnost za srićnu smrt" s poukama kako se pripremiti za smrt, molitvama i tumačenjima običaja za vrijeme pogreba, a na kraju o pobožnosti „za duše u mukah očistenja“, te pouku o dužnosti i načinu pomoći dušama u čistilištu, s litanijama i molitvama. ${ }^{13}$

Kanižlićeva Bogoljubnost molitvena ne obiluje samo raznovrsnim pobožnostima, molitvama, pjesmama, poukama i razmatranjima nego je i svojevrsno svjedočanstvo crkvenih običaja, vjerske prakse, crkvene terminologije ${ }^{14}$ i drugih vidova tadašnjeg vjerskog života, koje je Kanižlić sakupio, vjerojatno najviše iz požeškoga kraja, i zabilježio. Da je ta crkvena tradicija, zajedno s poukama, objašnjenjima i razmatranjima bila razumljiva i u drugim hrvatskim krajevima, pokazuju kasnija izdanja molitvenika od Zadra, Budima do Zagreba sve do konca 19. stoljeća.

\section{Kanižlić u izdanjima Vincenza Basilea}

Moglo bi se reći da je u drugoj polovici 19. stoljeća Kanižlića „oživio“ dalmatinski pučki misionar Vincenzo Basile (1811. - 1882.) svojim izdanjima njegovih djela. Rodom Sicilijanac, najprije od 1841. nakratko djeluje u Albaniji, a od 1843. je u Dubrovniku, potom je kao župnik u istočnoj Hercegovini naučio dobro hrvatski, tako da je zajedno s drugim Sicilijancem, Antonijem M. Ayalom, započeo 1852. držati pučke misije po hrvatskim krajevima. ${ }^{15}$

11 Usp. M. Vanino, Isusovci i hrvatski narod, II, Zagreb 1987, 641.

12 Te bratovštine muke i smrti Isusove vodili su u to vrijeme isusovci u svim svojim kućama i s puno članova te su bile vrlo popularne. O takovim bratovštinama u kajkavskom kraju vidi M Korade, Kajkavske bratovštine muke i smrti Isusove u 17. i 18. stoljeću, u: Muka kao nepresušno nadahnuće kulture. Pasionska baština kajkavskih krajeva, Zbornik radova XI međunarodnog znanstvenog skupa, Zagreb 2018, 464-486.

13 Opširne prikaze molitvenika ima M. Vanino, Isusovci, II, 640-641; III, 428-431.

14 Lijep primjer hrvatskih naziva crkvenih predmeta ima Kanižlić kada opisuje misničko ruho i donosi nazive: naglavnik (humerale), košulja (alba), pojas (cingulum), prikoramenica (stola), misnica (paramenta) itd. A. Kanižlić, Bogoljubnost molitvena, 41; M. Vanino, Isusovci, II, 641.

15 M. Korade, Misionar i kulturni radnik isusovac Vinko Basile (1811.-1882.), Vrela i prinosi, 13 (1982) 106154; Valent Miklobušec, Isusovci i hrvatski narod, IV, Zagreb 2007, 31-54. 
Već nekoliko mjeseci nakon dolaska u Dubrovnik Basile je priredio jednu knjigu na hrvatskom jeziku. Bio je to njegov prijevod (sigurno uz pomoć nekih domaćih ljudi) duhovne knjižice Pensateci bene francuskog isusovca i kasnijeg opata Bartola Baudranda (1701. - 1787.) pod naslovom Razmišljajte ova dobra, Oca Bartula Baudranda Družbe Isusove. Prinesenje u jezik slovinski po Ocu Vincenzu Basile iste Družbe, U Rimu, Slovotješnjica S. Skupa od Raširenja Vjere, 1944. $\left(12^{\circ}, 252 \text { str. }\right)^{16}$ Drugo izdanje izlazi iste godine kod tiskara Martecchinija u Dubrovniku. ${ }^{17}$ Djelo je bilo vrlo prikladno za poučavanje o vjerskim stvarima i dužnostima jer je obrađivalo glavne kršćanske istine, pokoru i obraćenje te glavne dužnosti svakog kršćanina. Sva poglavlja podijeljena su na tri kratka dijela: razjašnjenje teme, primjer i razmatranje. Na kraju je Basile dodao nekoliko molitava.

Na jednom primjerku Ayala je zapisao svojom rukom: „U tom izdanju rimske Kongregacije propagande tiskano je 1200 primjeraka, koji su već razdijeljeni badava po Dalmaciji. Izdanje koje je istovremeno izašlo u Dubrovniku, u kojemu nedostaju molitve, troškom biskupa Jederlinića, tiskano je oko 1200 primjeraka. ${ }^{\prime 18}$

Budući da su Basile i Ayala godine 1852. započeli držati pučke misije, kao što smo vidjeli, od Dubrovnika, po Dalmaciji i potom po drugim hrvatskim krajevima, ubrzo se pokazala potreba za novim izdanjem poučne knjige Razmišljajte. Tako već 1854 . u Zadru izlazi treće izdanje, ovaj put prilagođeno novom hrvatskom pravopisu, koji je 1848. uveo Ljudevit Gaj. Naslov glasi: Razmišljajte ova dobro otca Bartula Baudrand Družbe Isusove. Prinesenje u slovinski jezik s dodatkom molitavah. U Zadru Bratja Battara tiskari 1854. (16 ${ }^{\circ}, 208$ str.). Nakon Baudrandova teksta razmatranja Basile dodaje one molitve koje je stavio u prvom, rimskom izdanju: Pokorna ćutjenstva izvadjena iz svetoga Pisma, Posvetjenje sebe istoga srcu Isusovu, Zaglavljenje (121-134). Zatim slijedi novi podnaslov:

Različite molitve Otca Antuna Kanizlića (sic!) Družbe Isusove, pa na str. 135-208. donosi molitve jutarnje, večernje i one za vrijeme sv. mise. Zatim Svetootajstva ispovidi i pričěšénja, Dila različitih kripostih, Molitva za dobiti proštenje, Molitva za nevirnike

16 Naslov francuskog izdanja jest L'ame Penitente, ou le nouveau Pensez-y bien, Lyon 1778. Kasnije je knjiga, osobito u 19. stoljeću, doživjela brojna izdanja na francuskom i talijanskom, a prevođena je i na druge jezike. Basile je djelo preveo s talijanskog.

17 Razmišljajte ova dobro otca Bartola Baudrand, Družbe Jezusove. Prinešenje u jezik slovinski, U Dubrovniku, Slovotješnjica Martekini, 1844, 16 182 str. Primjerak ima franjevačka knjižnica na Trsatu, vidi FrkinHolzleitner, Bibliografija, 79.

18 „Di questa edizione Romana della S. Congr. di Propaganda ne fece tirare 1200 copie; che furono di già dispensate per la Dalmazia gratuitamente. Dell'edizione fatta contemporaneamente a Ragusa, nella quale mancano le preghiere, a spese di Mons. Jederlinich se ne tirarono circa mille e ducento." (Primjerak Razmišljajte iz jedne splitske knjižnice). Tomo Jederlinić bio je 1843. - 1855. dubrovački biskup. Antonio Maria Ayala (1818. - 1887.) iz plemićke obitelji kod Catanije na Siciliji, od 1845. djeluje u Hercegovini, a od 1852. do smrti kao pučki misionar u našim krajevima. Umro je u Splitu. Vidi: M. Korade, Misionar, 110; V. Miklobušec, Isusovci, IV, 55-62. 
i grišnike Svetoga Frančiska Saveria, Molitva B. D. M. Sv. Bernarda, Priporuka istoj B. D. M., molitva sv. Josipu, molitva sv. Alojziju, Pohvala prisv. Imenu Božjemu i na kraju Za očuvati čistoću i Uzdahnutja (tj. pobožni uzdasi ili izreke). Razvidno je da je Basile napravio izbor molitava iz Kanižlićeve Bogoljubnosti molitvene, i to sigurno iz trećeg zadarskog izdanja (tiskanog kod istog tiskara Battare), ispustivši one duge pouke i objašnjenja što su pratili spomenute molitve. To zadarsko izdanje tiskano je u 4.000 primjeraka. ${ }^{19}$

U molitvama je jasno vidljiv Kanižlićev jezik (ikavica), drugačiji od ostatka djela Razmišljajte (Basile je naučio i piše dubrovačkom ijekavicom). Svakako je važno naglasiti da su misionari u prvim godinama svoje djelatnosti po svim hrvatskim krajevima dijelili svoj književni prvijenac s molitvama Antuna Kanižlića, sve do 1863., kada tiskaju vlastiti misijski molitvenik: Molitvenik za katolička poslanstva po slovinskih državah na jugu (Verona 1863).

Nakon što je Basile proveo nekoliko godina u Požegi (1862. - 1865.) kao duhovnik u tamošnjem orfanotrofiju, odlazi u Rim i tamo 1865. objavljuje novo (četvrto) izdanje Baudrandova prijevoda, treće izdanje misijskog Molitvenika i još nekoliko priručnika za bratovštine i druge udruge koje su misionari uvodili i promicali na svojim misijama. Ta je izdanja objavio kako bi ih donio u Zagreb i time potaknuo osnivanje ustanove za tiskanje hrvatskih knjiga. ${ }^{20}$

Novo, četvrto izdanje Baudrandova prijevoda glasi: Razmišljaj ovo dobro. Napisao o. Bartol Baudrand Družbe Isusove, a preveo O./tac/ V.linkol B./asilel iste Dr./užbel, za katolička poslanstva po slovinskih državah na jugu. S dodatkom molitavah i razmišljanjah. Četvrto izdanje popravljeno. Cjelopis. U Rimu, tiskano pri Skupu za rasplodjenje vjere pod upravit. druga Petra Marietti-a 1865. $\left(16^{\circ}, 114+1\right.$ str.). Izdanje je lijepo dotjerano u tečnoj i čistoj štokavskoj ijekavici, pri čemu su mu pomogli hrvatski kanonici pri Sv. Jeronimu u Rimu, kako sâm Basile spominje u predgovoru. ${ }^{21}$

Dodatak s posebnom paginacijom na 138 stranica ima naslov: Dodatak. Promišljanja i molitve o. Antuna Kanižlića Dr.lužbel Is./usovel. Zatim slijedi Nauk ob osobitoj molitvi iliti promišljanju (str. 3-14). To je ona pouka o mislenoj molitvi iz Bogoljubnosti molitvene, a zatim slijede iz istog molitvenika Kratka promišljanja o posljednjih četiriju stvari za svaki dan u mjesecu (15-43). Slijede Razlike molitve: molitve jutarnje, večernje i za svete mise. Potom Svetootajstvo ispoviedi i pričesti i druge molitve (Djela različitih kriepostih, Molitva za proštenje griehah itd.), kao i u dodatku iz 1854.

19 M. Korade, Misionar, 125.

20 Plan je Basile zajedno s Ayalom 1866. iznio pred zagrebačkim nadbiskupom kardinalom Jurjem Haulikom i dopremio knjige, a on je na njihov poticaj 1868. osnovao „Književno društvo sv. Jeronima“ za širenje dobrog tiska među Hrvatima. M. Korade, Misionar, 129-133.

21 Ispred naslovne je stranice grafika s Isusom na križu, a ispod su apostol Ivan, Isusova majka Marija i Marija Magdalena. Ispod slike je natpis „Isuse moj! Smilovanje!“. 
Međutim, ovdje Basile dodaje nekoliko novih molitava, pjesama i pobožnosti. To su Krunica u slavu božanskoga Srdca Isusova, Prieporuka Andjelu Čuvaru, Molitva ss. Apostolom slavenskim Ćirilu i Metodu, krunica na slavu sv. Alojzija, krunica na čast sv. Stanislavu Kostki, prošnje bl. Ivanu Berchmansu te pjesme Duhu Svetome, pokorna pjesma kralja Davida (Ps. 50), Iz dubina vapijem, Tebe Boga hvalimo i Tantum ergo. Od tih pjesama neke su također iz Kanižlićeva molitvenika. Na kraju je Molitveno apoštolstvo (str. 124-135), tj. pravila, molitve i oprosti Apostolata molitve. Te nove pobožnosti (osobito Srcu Isusovu i Marijinu, Apostolat molitve, svetima Ćirilu i Metodu i dr.) i molitve (uz pjesme koje su se najčešće pjevale u misijama) Basile i drugi misionari uvodili su i promicali na svojim pučkim misijama, a tu su i tri isusovačka sveca, zaštitnici mladeži (sv. Alojzije, sv. Stanislav i bl. Ivan Berchmans, koji je te 1865. godine bio proglašen blaženim).

Osim toga dodatka uz Razmišljaj ovo dobro postoji i zasebno izdanje, koje na koricama ima naslov: Kratka promišljanja i molitve o. Antuna Kanižlića Dr. Isus... S' Apoštolstvom molitve za katolička poslanstva po Slovincih na jugu. Isti je naslov na prvoj stranici, a zatim slijedi na istoj naslovnici: „Cjelopis. U Rimu, tiskano pri Skupu za rasplodjenje vjere pod upravit. druga Petra Marietti-a 1865“, $\left(12^{\circ}, 138\right.$ str.). Ispred naslovne je stranice zasebnog izdanja slika bl. Ivana Berchmansa. I u zasebnom je izdanju sadržaj identičan i s istim brojem stranica s onim u dodatku knjige Razmišljaj. To je rimsko izdanje tiskano u 3.000 primjeraka, a zasebno izdanje Kratkog promišljanja imalo je nakladu od 6.000 primjeraka. ${ }^{22}$ Basile, Ayala i drugi pučki misionari do kraja 19. stoljeća u južnim hrvatskim su krajevima od Boke do Istre održali oko tisuću misija ${ }^{23}$, a činjenica da su na svojim misijskim pohodima promicali Kanižlićeve molitve i promišljanja, jer su one služile kao neka vrst misijskog priručnika, pokazuje da je naš slavonski pjesnik i pisac bio itekako poznat i popularan u 19. stoljeću u južnim dijelovima svoje domovine.

Za vrijeme boravka u Požegi Basile je priredio ponovno izdanje jednog drugog (i to čitavog) Kanižlićeva djela. Radi se o djelu s neobičnim i dugim naslovom, a počinje ovako: Primogući i sardce nadvladajući uzroci s-kripostnimih potpomoćmah za ljubiti Gospodina Isukarsta Spasitelja našega sa svim sardcem, sa svom dušom i sa svom jakostju. U Zagrebu, Od Cajetana Franc. Härl, 1760. ( $8^{\circ}$, [16]+270+[2] str.). U dugačkom naslovu Kanižlić napominje da je djelo preradio prema jednom njemačkom izdanju, koje je isprva bilo objavljeno na francuskom jeziku. To su duhovna razmatranja francuskog

22 Tako navodi Ayala u jednom spisu u kojemu donosi sva izdanja dalmatinskih misionara. M. Korade, Misionar, 128-129.

23 Budući da sam doktorirao na pučkim misijama tih misionara (usp. M. Korade, La "Missione Illirico-Dalmata" dei gesuiti (1852-1900) Svolgimento, metodo e risultati, Zagreb 1989), izradio sam detaljan popis svih misija i drugih aktivnosti koje su misionari obavljali u našim krajevima i imam ga u svojim bilješkama. 
isusovca Françoisa Nepveua (1639. - 1708.) pod naslovom: De l'amour de Notre Seigneur Jésus-Christ et des moyens de l'acquérir (Nantes 1684), koje je potom doživjelo mnoga izdanja i bilo je prevođeno na njemački, engleski, španjolski, nizozemski, a na talijanski je djelo preveo poznati talijanski misionar i književnik Paolo Segneri St. Postoji i starije hrvatsko izdanje koje je, najvjerojatnije od Segnerijeva talijanskog prijevoda, preveo i priredio Dubrovčanin Dominik Bianković: Od ljubavi Isusove i od načina za steći je. Pismo oca Fr. Nepueu prinešeno u jezik slovinski, Mletci po Fr. Storti, 1722. ( $8^{\circ}, 154$ str.). Kanižlić vjerojatno nije poznavao to hrvatsko izdanje.

Teško je Kanižlićevo izdanje nazvati prijevodom, to je više slobodna prerada s puno vlastitih dodataka, a od izvornika je preuzeo dva od tri dijela. U prvom se dijelu raspravlja o osam razloga koji mogu potaknuti čovjeka na ljubav prema Isusu, a u drugom o osam sredstava kako se ta ljubav može postići. Raspravama je dodao nekoliko manjih duhovnih pjesama i dva velika spjeva, o sv. Alojziju i mladiću Urbanu. U dugom predgovoru govori o pismenosti, jeziku i pravopisu, osobito o razlici između naziva i jezika "račkog" i hrvatskog. ${ }^{24}$

Dakle, Basile je u Požegi priredio novo izdanje s promijenjenim, svakako razumljivijim i spretnijim naslovom:

Važni uzroci s kojih Gospodina Isukrsta Spasitelja našega nada sve ljubiti moramo $i$ njeka spasonosna sredstva kojimi se ova ljubav probuditi može. Preveo Antun Kanižlić, Požežanin i Družbe Isusove misnik, a preradio jedan svećenik. U Požegi 1864. Tiskarna Miroslava Kraljevića, $\left(12^{\circ}\right.$, XII+296 str.). Isusovački bibliograf Carlos Sommervogel ${ }^{25}$ to je izdanje pripisao hrvatskom isusovcu Antunu Meseku (1836. - 1912.), prema jednom popisu hrvatskih djela Austrijske provincije (1814. - 1906.), kojoj je Mesek pripadao i tada je zajedno s Basileom djelovao u Požegi. ${ }^{26}$

Moguće je da je Mesek pomogao Basileu, osobito savjetom što se tiče jezika, u priređivanju djela, ali je i sam Basile bio sposoban za takvo što, s obzirom na to da je davno prije već od Dubrovnika pa dalje priređivao slična djela. U naslovu se samo spominje da je djelo „preradio jedan svećenik“, a i na kraju posvete kardinalu Jurju Hauliku također stoji: „ovo prerađeno djelo posvećuje u smiernoj podanosti jedan svećenik “. ${ }^{27}$ Međutim, u Nadbiskupskom arhivu u Zagrebu postoji nekoliko pisama Basilea kardinalu Hauliku u kojima mu piše da je priredio dotično Kanižlićevo djelo te moli kardinalovu potporu za njegovo objavljivanje. Iz te korespondencije Basilea $s$ kardinalom očito je da je on priredio djelo i objavio uz kardinalovu potporu posve-

24 Dijelove predgovora donosi Tomo Matić, Život i rad Antuna Kanižlića, Stari pisci hrvatski, 26 (1940) XXIV-XXIX. Usp. M. Vanino, Isusovci, III, 457-459.

25 Carlos Sommervogel, Bibliothèque de la Compagnie de Jésus, IV, Bruxelles - Paris 1892, col. 908.

26 Mesek je bio najstariji hrvatski isusovac koji je pripadao Austrijskoj provinciji i djelovao tada u Hrvatskoj. O njemu vidi Josip Badalić, O. Antun pust. Mesek D., I., u: Kamilo Zabeo, Travnička spomenica, Travnik 1932, 272-273.

27 Antun Kanižlić, Važni uzroci, Požega 1864, nepag. 
tivši, na stranici nakon naslova, njemu to izdanje. ${ }^{28}$ Osim toga, Ayala u već spomenutom popisu izdanja koja su priredili dalmatinski misionari navodi i to djelo te da je tiskano u 2.000 primjeraka. ${ }^{29}$

Basile je dosta skratio Kanižlićev dugi predgovor i izostavio onaj dio o Racima i Šokcima, ${ }^{30}$ zatim slijedi djelo u cijelosti, a na kraju je dodao Pridavak sa svakodnevnim molitvama (str. 247-296). Kanižlićev je tekst Basile preuredio prema novom pravopisu s dijakritičkim znakovima i njegovu ikavicu pretočio u štokavsku ijekavicu.

Usput spominjem na koji su način u proznom Kanižlićevu tekstu uklopljeni njegovi stihovi (prema Basileovu izdanju). Među ostalim u prvom dijelu jest i pjesma o sv. Ignaciju koja počinje: Ignacije je bio izgled ljubavi Boga (str. 52-55). U drugom dijelu, u raspravi o osmom sredstvu kako zadobiti ljubav prema Bogu, jest dugačka Pjesma o sv. Alojziji, mladiću angjeoskome (str. 187-218). Priča o mladiću Urbanu uklopljena je u Zaglavak. O znacih da li ljubimo Gospodina našega Isukrsta (219-239), te je bez posebnog naslova ispričana, naizmjence $u$ prozi i stihovima, pripovijest o Urbanu, koji se iz grješnog života obratio Bogu (223-239). ${ }^{31}$

Još bi se jedno ponovljeno izdanje Kanižlićevih djela moglo povezati s Basileom. Donosim to kao hipotezu jer nemam za to čvrstih dokaza. Naime, Kanižlićev spjev Sveta Rožalia panormitanska divica nakićena i ispivana po Antunu Kanižliću Požežaninu (Beč 1780) ponovno je objavio 1863. u Požegi, kao drugo izdanje, požeški tiskar Miroslav Kraljević. On je preinačio Kanižlićeve dvanaesterce u šesterce, a u pogovoru je naglasio važnost tog pjesničkog djela. Lako je moguće da je Basile, koji je u Dalmaciji prijašnjih godina objavljivao i promicao u misijama dijelove Kanižlićeve Bogoljubnosti molitvene, potaknuo tiskara Kraljevića na ponovno izdanje Svete Rožalije, a možda je i sudjelovao u njegovoj pripremi i objavljivanju. Uz to je već iduće godine kod istog tiskara pripremio novo izdanje još jednog Kanižlićeva djela (Važni uzroci) i pobrinuo se za troškove tiska. U svakom slučaju, kada je 1862. Basile došao u Požegu, već je sigurno bio poznat kao velik štovatelj Kanižlića i njegovih djela, što je i u njegovu rodnom gradu novim izdanjem i potvrdio, pa ne bi bilo čudno da je njegov utjecaj bio presudan i u ponovnom izdanju Sv. Rožalije.

28 Usp. Juraj Lahner, Zamisao isusovca o. Vinka Basilea i Hrvatsko književno društvo sv. Jeronima, Marulić, 13 (1980, 1, 83, bilj. 2.).

29 M. Korade, Misionar, 127-128. Novine „Katolički list“ iste, 1864. godine donijele su najavu (str. 384) i recenziju (str. 416) Važnih uzroka, i tu se uvijek navodi da je djelo priredio ,jedan svećenik“.

30 Antun Kanižlić, Važni uzroci, VII-XII.

31 Još je jedno, jako skraćeno, izdanje tog djela objavio isusovac Matija Kulunčić pod naslovom (s pogrešnim autorovim prezimenom): F. Nepuen D. I., Ljubimo Isusa. Preveo M. Kulunčić D.I., Zagreb 1937, mala $8^{\circ}, 82+[2]$ str. U predgovoru Kulunčić napominje da je djelo prvi pohrvatio A. Kanižlić, a budući da je „toga prvoga izdanja nestalo, evo sada novi prievod s novim dodatkom trećega dijela od o. Segneria“. Naime, talijanski Segnerijev prijevod ima sva tri dijela Nepueva djela, a Kanižlićev samo dva dijela, no Kulunčićev je prijevod jako skraćen i sažet, s obzirom na oba ta izdanja, pa je upitno koliko je Kulunčić uzeo od Kanižlićeva izdanja. 
Još je jedan talijanski isusovac, koji djeluje u Dalmaciji, zaslužan za promociju Kanižlića u južnim hrvatskim krajevima u 19. stoljeću. Bio je to Cesare Luigi Ferrari (1827. - 1883.) iz Verone, koji 1856. - 1868. djeluje u Dubrovniku kao gimnazijski profesor, a naučivši dobro hrvatski, od 1863. propovijeda na hrvatskom jeziku. Od 1869. pa sve do smrti 1883. profesor je hrvatskog, povijesti talijanske književnosti i vjeronauka u sjemeništu Zmajević u Zadru. U Dubrovniku je objavio molitvenik Blago duhovno ili molitve nadarene svetiem proštenjima na upotrebljenje $i$ korist bogoljubne Braće Prisv. Serca Jezusa i Marije u Dubrovniku, Verona, Figli di Maria 1865. (16º 232 str.). Ferrari je u molitvenik uvrstio molitve i razmišljanja starih hrvatskih pisaca, Bartola Kašića, Antuna Kanižlića, Ive Marije Matijaševića i drugih te misijskog Molitvenika. ${ }^{32} \mathrm{Uz}$ to je preveo na hrvatski zbirku svibanjskih propovijedi (Mese di Maggio), koja nije tiskana. Kao profesor u Zadru bavio se osobito crkvenom poviješću Dalmacije i objavio na talijanskom nekoliko djela i prigodnih radova sa svojim učenicima. Najvažnija su mu: Memoria dei santi martiri Grisogono e Anastasia patroni di Zara, Venezia, Tip. Emiliana, 1874. ( $8^{\circ}, 149$ str.), i Litanie dei Santi della Dalmazia, Zara, Tip. Artale, 1882. $\left(12^{\circ}, 67 \text { str. }\right)^{33}$

Ostaje otvoreno pitanje ima li kakve povezanosti između Kanižlićeve Bogoljubnosti molitvene i misijskog Molitvenika koji su Basile i drugi misionari objavljivali u velikoj nakladi kroz 19. stoljeće. Molitvenik za katolička poslanstva po jugoslovinskih deržavah na jugu doživio je više izdanja: 1. izdanje Verona 1863. ${ }^{34}$ (tiskano u 6.500 primjeraka), 2. izd. Verona 1864. (11.500 primj.), 3. izd. Rim 1865. (3.000 primj.), 4. izd. Zadar 1876., 5. izd. Krk 1902. Moglo bi se pomisliti da Basile aludira na Kanižlića kada u predgovoru trećeg izdanja Molitvenika (Rim 1865), između ostaloga, kaže: „U zalog ljubavi moje prema Tebi mili Narode! evo ti milošće i spomenika iz sv. Rima; evo ti 'Molitvenika' Tebi jurve dobro poznata i omiljela... Pretiskan je i ov put onako kako ga napisao prepoštovani njeki svećenik, revan oplemenitelj Tvoga prekrasnoga jezika." ${ }^{\prime 35}$

Vidjeli smo da se istom sintagmom „njeki svećenik“ Basile koristio i u izdanju Važnih uzroka (1864.), pa možda i ovdje tim izrazom označava samoga sebe, premda nije sigurno da je on jedini sastavljač Molitvenika. Naime, Basile se nakon trogodišnjeg boravka na Siciliji vraća 1861. u Hrvatsku, a početkom 1862. odlazi u Požegu za

\footnotetext{
32 M. Korade, Misionar, 129.

33 /Ermenegildo Baccolo/, Catalogo dei libri pubblicati dai padri d. C. d. Gesú della Provincia Veneta dell'anno 1847-1888., Modena 1889, 16; „Katolička Dalmacija”, 14 (1883) br. 71, 11. X.

34 Primjerak toga prvog izdanja iz 1863. nedavno sam našao u knjižnici Metropolitana u Zagrebu. Kada sam prije 37 godina pisao o misionaru Basileu, nisam poznavao taj primjerak, a povodeći se za spomenutim Ayalinim popisom u kojemu navodi da je prvo izdanje Molitvenika izašlo 1861., tako sam i ja naveo $\mathrm{u}$ istome članku, što sada ispravljam. M. Korade, Misionar, 126.

35 Vincenzo Basile, Molitvenik za katolička poslanstva, Rim 1865, 3; M. Korade, Misionar, 126-127.
} 
duhovnika u tamošnjem orfanotrofiju. ${ }^{36}$ Tamo je pripremio tekst molitvenika za tisak, ali je u toj pripremi na neki način sudjelovao i Ayala, s obzirom na to da su se tim tekstovima obojica koristili u misijama prijašnjih godina, pa su ih najvjerojatnije sakupili zajedno. Zato se u prva dva izdanja ne navodi autor, a i Ayala u navedenom popisu ne navodi autora Molitvenika. Naravno, Ayala apsolutno nigdje ne spominje koliko je i kako je sudjelovao u izdanju Molitvenika i drugih misijskih priručnika i brošura.

Važno je spomenuti da su prva dva izdanja Molitvenika pisana ikavicom, da nemaju nikakvog predgovora i da preko polovice teksta sadrži razne nove pobožnosti koje su misionari uvodili na misijama. U tekstu su izmiješane te nove pobožnosti s raznim molitvama i pjesmama. koje samo ponegdje nalikuju na Kanižlićeve, ali nisu identične s njegovim u Bogoljubnosti molitvenoj. Svakako je Kanižlićev molitvenik misionarima bio inspiracija i poticaj u sakupljanju molitava i pobožnosti za potrebe njihovih misija (koje su u svakom novom izdanju nadopunjavali, a od trećeg izdanja Molitvenik je pisan ijekavicom, kao što smo vidjeli), što je, uz ostalo, i potaknulo Basilea da zasebno objavljuje razmišljanja i molitve iz njegova molitvenika.

\section{Zaključak}

Najprije su Kanižlićeve pjesme te molitve i razmišljanja bili vrlo popularni u južnim dijelovima Hrvatske zahvaljujući najviše Basileovim izdanjima, pri čemu je od Kanižlićevih knjižica učinio pravi misijski priručnik. Te su knjižice misionari dijelili na svojim pohodima, a najviše su misija do kraja 19. stoljeća uglavnom i jedino kontinuirano održavali $u$ dalmatinskim i priobalnim biskupijama. Zahvaljujući misionaru Vincenzu Basileu, i druge Kanižlićeve knjige doživljavaju ponovna izdanja, također u 19. stoljeću. Valja na kraju naglasiti da je Basile zaslužan što su Kanižlićeva djela izdavana i čitana kroz čitavu drugu polovicu 19. stoljeća, a Ivekovićevo izdanje Kanižlićeva molitvenika proširilo je njegovu prisutnost u hrvatskim krajevima tijekom prve polovice 20. stoljeća.

\section{Izvori i literatura}

Diarium missionis, I, 1852-1866., rkp., Knjižnica „Juraj Habdelić“, Zagreb.

Vincenzo Basile, Razmišljajte ova dobro otca Bartola Baudrand, Dubrovnik 1844.

/Vincenzo Basile/, Molitvenik za katolička poslanstva, Rim 1865,

/Vincenzo Basile/, Kratka promišljanja i molitve o. Antuna Kanižlića, Rim 1865.

Bartol Baudrand, L'ame Penitente, ou le nouveau Pensez-y bien, Lyon 1778.

Antun Kanižlić, Bogoljubnost molitvena, 3. izd., Zadar /1806/.

36 Knjižnica "Juraj Habdelić“, Zagreb, Diarium missionis, I, 1852-1866. 233. 
Antun Kanižlić, Važni uzroci s kojih Gospodina Isukrsta Spasitelja našega nada sve ljubiti moramo, Požega 1864.

/Ermenegildo Baccolo/, Catalogo dei libri pubblicati dai padri d. C. d. Gesú della Provincia Veneta dell'anno 1847-1888., Modena 1889.

Josip Badalić, O. Antun pust. Mesek D., I., u: Kamilo Zabeo, Travnička spomenica, Travnik 1932.

Josip Buturac, 100 godina Hrvatskog književnog društva sv. Jeronima ili sv. Ćirila i Metoda 1868-1968, Zagreb 1969.

Vatroslav Frkin i Miljenko Holzleitner, Bibliografija knjiga hrvatskih autora u knjižnicama Hrvatske franjevačke provincije sv.Ćirila i Metoda 1495.-1850., HAZU, Zagreb 2008.

Josip Jakšić, Četiri stoljeća hrvatskih katekizama, 1578-1980, Zagreb 1995.

Mijo Korade, Hrvatski isusovci misionari, Zagreb 1991.

Mijo Korade, Kajkavske bratovštine muke i smrti Isusove u 17. i 18. stoljeću, u: Muka kao nepresušno nadahnuće kulture. Pasionska baština kajkavskih krajeva, Zbornik radova XI. međunarodnog znanstvenog skupa, Zagreb 2018, 464-486.

Mijo Korade, Misijski katekizmi u južnoj Hrvatskoj u 18. stoljeću, Kateheza, 20 (1998) 4, 341-348.

Mijo Korade, Misionar i kulturni radnik isusovac Vinko Basile (1811.-1882.), Vrela i prinosi, 13 (1982) 106-154.

Mijo Korade, La "Missione Illirico-Dalmata“ dei gesuiti (1852-1900) Svolgimento, metodo e risultati, Zagreb 1989.

Juraj Lahner, Zamisao isusovca o. Vinka Basilea i Hrvatsko književno društvo sv. Jeronima, Marulić, 13 (1980) 1, 80-84.

„Katolička Dalmacija“, 14 (1883) br. 71.

„Katolički list", 1864.

Tomo Matić, Pjesme Antuna Kanižlića, Antuna Ivanošića i Matije Petra Katančića, Stari pisci hrvatski, 26, MH, Zagreb 1940.

Valent Miklobušec, Isusovci i hrvatski narod, IV, FTI, Zagreb 2007.

F. Nepuen D. I., Ljubimo Isusa. Preveo M. Kulunčić D.I., Zagreb 1937.

Carlos Sommervogel, Bibliothèque de la Compagnie de Jésus, IV, Bruxelles-Paris 1892.

Miroslav Vanino, Isusovci i hrvatski narod, (priredio za tisak i dopunio M. Korade), II, FTI, Zagreb 1987; III, FTI, Zagreb 2005. 


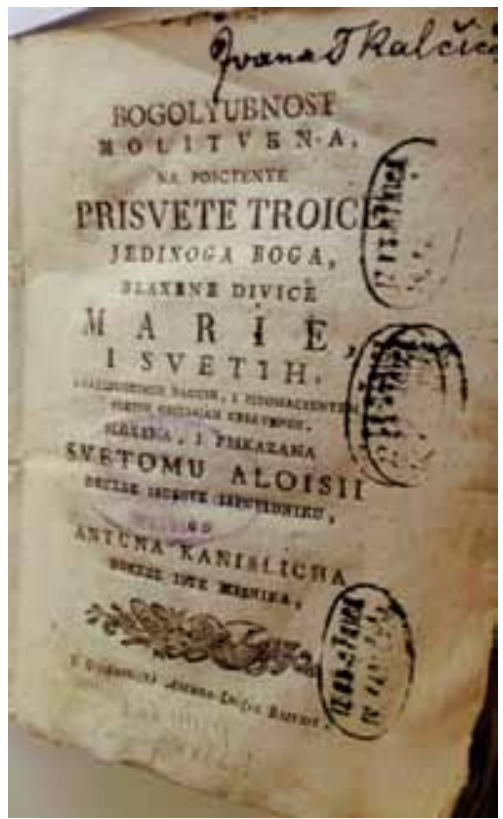

Slika 1. „Bogoljubnosti molitvena“, zadarsko izdanje 1806.

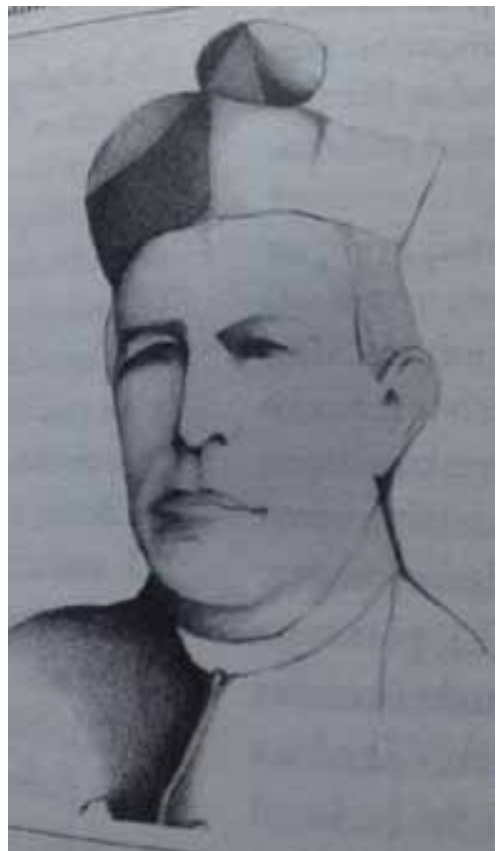

Slika 2. Vincenzo Basile, pučki misionar 
Radovi Zavoda za znanstveni i umjetnički rad u Požegi, 8 (2019), str. 101-119

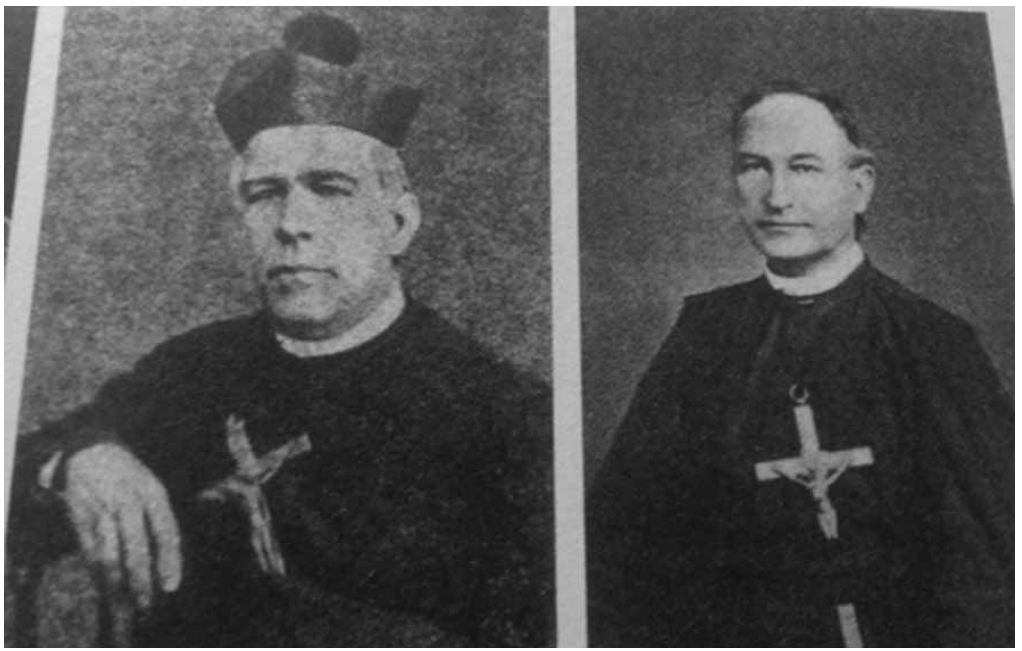

Slika 3. Dva dalmatinska misionara Basile i Ayala

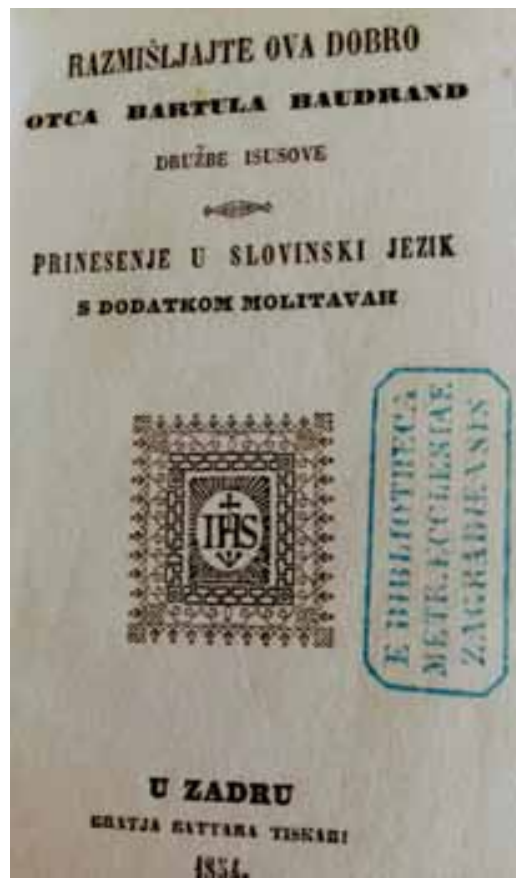

Slika 4. "Razmišljajte ova dobro", 1854. u kojem se prvi put pojavljuje Dodatak s Kanižlićevim molitvama 


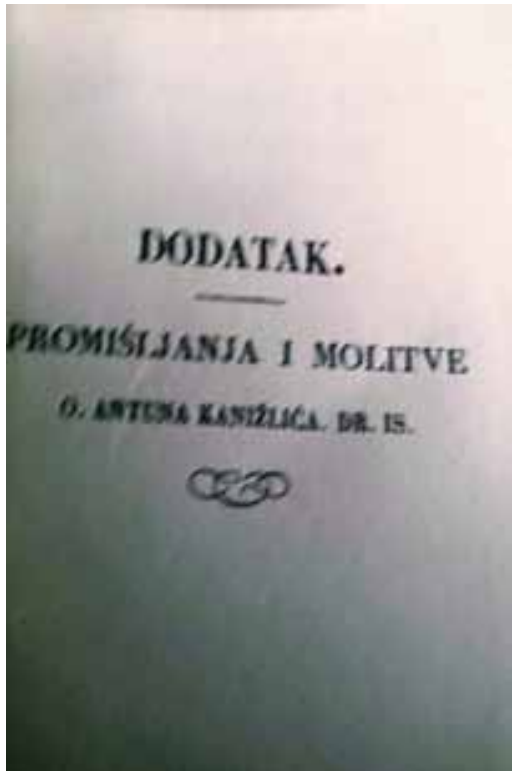

Slika 5. Dodatak Kanižlićevih razmišljanja i molitava u "Razmišljaj ovo dobro“ iz 1865.

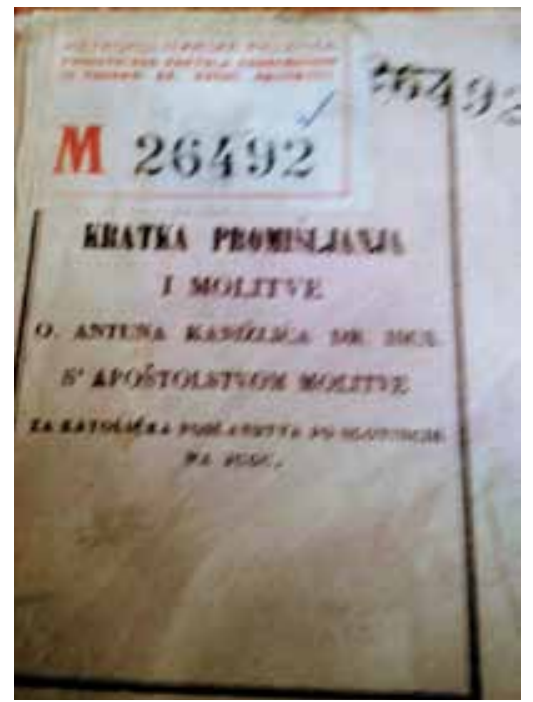

Slika 6. Kratka promišljanja i molitve A. Kanižlića, 1865., korice zasebnog izdanja 


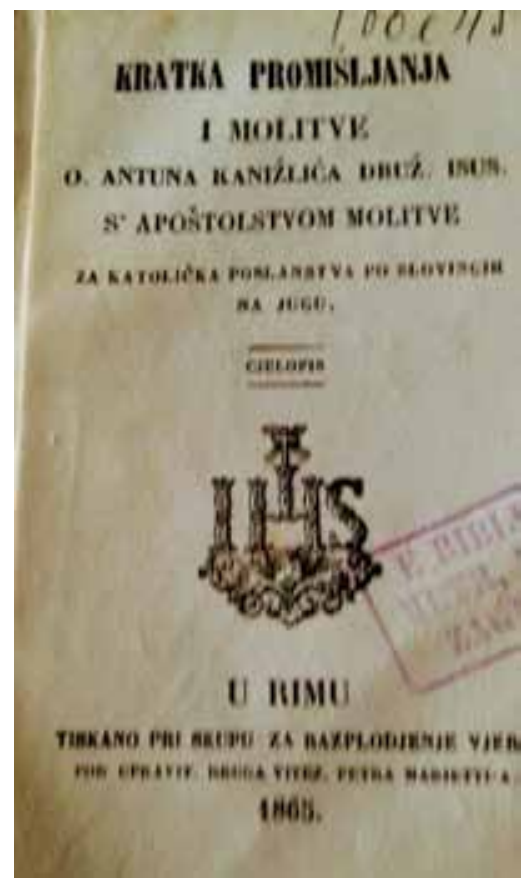

Slika 7. Kratka promišljanja i molitve Antuna Kanižlića, zasebno izdanje, 1865., naslovnica

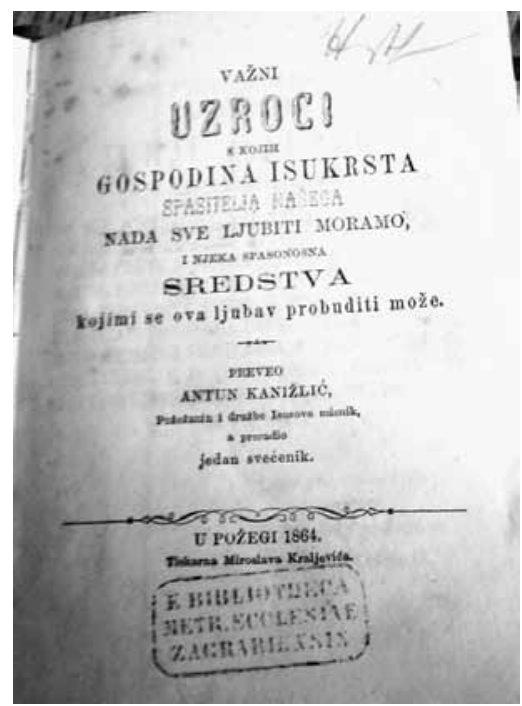

Slika 8. Važni uzroci (Basileovo izdanje) 
Radovi Zavoda za znanstveni i umjetnički rad u Požegi, 8 (2019), str. 101-119

M. Korade: Antun Kanižlić i Vincenzo Basile: Kanižlićeva djela u Dalmaciji u 19. stoljeću

\section{Antun Kanižlić and Vincenzo Basile: Kanižlić's Works in Dalmatia in the 19th Century}

\section{Summary}

The paper intents to define to what extent and in which fashion were Kanižlićs s works present in Dalmatia and Southern Croatia in general in the $19^{\text {th }}$ century. A number of Kanižlić's poems (e.g. Pismu novu svi pivajmo) had already been included in the mission book / the book of poems by missionaries from Rijeka, entitled Knižica duhovna (Trnava 1768). The prayer book Bogoljubnost molitvena by Antun Kanižlić had its third edition published in 1806 by the Zadar printer Battara. Sicilian Jesuit Vincenzo Basile, who together with Antonio Ayala began his missionary's visits in 1852 - first in Dalmatia and later across Croatia, included Kanižlić's prayers in the third edition of his booklet of spiritual contemplations, entitled Razmišljajte ova dobro oca Bartola Baudrand (Zadar 1854). An appendix with a separate pagination, entitled Kratka promišljanja i molitve oca Antuna Kanižlića, was included in the fourth edition of the same work - Razmišljajte ova dobro (Rome 1865). This appendix was also published as a separate booklet $\left(12^{\circ}, 135\right.$ pages), which included thoughts for every day of the month, daily prayers, liturgical prayers for the holy mass, confession and communion prayers, and prayers to particular saints; all of these were taken from the prayer book Bogoljubnost molitvena.

Basile further prepared a new edition of Kanižlić's work Primogući i sardce nadvladajući uzroci s kripostnimih podpomočmah za ljubiti Gospodina Isukarsta Spasitelja našega... (Zagreb 1760), with a new title and in line with the new orthography: Važni uzroci s kojih Gospodina Isukrsta Spasitelja našega nada sve ljubiti moramo i njeka spasonosna sredstva kojim se ova ljubav probuditi može (Miroslav Kraljević, Požega 1864). Basile shortened Kanižlić's foreword and added daily prayers. Italian Jesuit Cesare Luigi Ferrari published a prayer book entitled Blago duhovno ili molitve nadarene svetiem proštenjima... (Verona 1865) for a society from Dubrovnik. This book includes Kanižlić's prayers and contemplations, as well as those of other earlier writers (B. Kašić, I. M. Matijašević, et al.). Molitvenik za katolička poslanstva po jugoslovinskih deržavah, a manual for Dalmatian missionaries, which had been published in five editions between 1863 and 1902, is in many ways dependent on and connected to Kanižlić's prayer book Bogoljubnost molitvena.

Keywords: Antun Kanižlić; Vincenzo Basile; Dalmatia; $19^{\text {th }}$ century; prayer books; missionary's visits.

Prof. dr. sc. Mijo Korade

Hrvatski studiji Sveučilišta u Zagrebu

Borongajska cesta 83d, 10000 Zagreb

mkorade@hrstud.hr 
